\title{
Abolition of the seasonal release of luteinizing hormone and testosterone in Alpine male goats (Capra hircus) by short photoperiodic cycles
}

\author{
J. A Delgadillo* and P. Chemineau $\dagger$ \\ INRA Physiologie de la Reproduction, Nouzilly, 37380 Monnaie, France
}

\begin{abstract}
Summary. This study was performed to determine whether rapid alternation between long and short days abolished seasonal variations in the activity of the hypothalamo-pituitarytestis axis observed normally in Alpine and Saanen male goats during the year. Three groups of 6 males were used: group 1 remained in open sheds under the natural annual change in daylength from $16 \mathrm{~h}$ of light (long day) to $8 \mathrm{~h}$ of light (short day). Group 2 was exposed to 1 month of long days alternated with 1 month of short days; and group 3 to 2 months of long days alternated with 2 months of short days. In group 1, blood samples were taken in December, February and June; in groups 2 and 3, samples were obtained once during short and long days for the melatonin assay. For luteinizing hormone and testosterone determinations monthly samples from group 1 were obtained from September to August while, in groups 2 and 3, blood samples were taken on 4 occasions during long and short days. Weekly blood samples were taken from all groups during the whole of the experiment to measure prolactin and testosterone concentrations.

Melatonin profiles indicated that secretion by the pineal gland of male goats from the treated groups adapted to rapid changes in daylength: duration of nocturnal secretion was close to that of the dark period. Treated goats were also able to transduce this signal adequately and always responded to long days by increasing their prolactin concentration (mean \pm s.e.m.; group 2: $62.4 \pm 6.8 \mathrm{ng} / \mathrm{ml}$; group 3: $102.3 \pm 15.7 \mathrm{ng} / \mathrm{ml}$ ) and to short days with a decrease in prolactin concentrations $(35.0 \pm 3.6$ and $46 \cdot 1 \pm 9 \cdot 5 \mathrm{ng} / \mathrm{ml}$, respectively). In the treated groups, luteinizing hormone pulse frequency varied with day length. In group 2 , it was higher in long days $(1 \cdot 1 \pm 0 \cdot 3$ pulses in 8 hours) than in short days $(0 \cdot 7 \pm 0 \cdot 3)$ while, in group 3 , this frequency was higher in short days $(1.9 \pm 0.3)$ than in long days $(0.5 \pm 0.2)$. Testosterone secretion also varied with daylength; in group 2 , the testosterone concentrations were maximum during long days $(5.8 \pm 1.4 \mathrm{ng} / \mathrm{ml})$ while in group 3 the maximum testosterone concentrations occurred during short days $(6 \cdot 4 \pm 1 \cdot 2 \mathrm{ng} / \mathrm{ml})$.

These results lead to the conclusion that rapid alternation of long and short days either attenuated (group 3) or prevented (group 2) seasonal changes in the activity of the hypothalamo-pituitary axis. The maintenance of high testicular weight and high sexual activity was due to periods of gonadotrophin stimulation of the testis alternating rapidly with periods of quiescence.
\end{abstract}

Keywords: seasonality; luteinizing hormone; testosterone; photoperiod; goat

\section{Introduction}

Male goats originating from temperate regions display marked seasonal variation in reproductive activity. The breeding season begins in autumn and ends in winter (Chemineau et al., in press). Reproductive activity as in sheep, is mainly entrained by photoperiodic changes, altering the

\footnotetext{
*Present address: Universidad Autónoma Agraria Antonio Narro, Carretera a Sta. Fé y Periférico. Apdo. Postal 940, Torreón, Coahuila, México.

tReprint requests.
} 
pattern of secretion of pineal melatonin, which induces changes in gonadotrophin secretion (Chemineau et al., 1986; Lincoln \& Short, 1980). Short or decreasing days stimulate secretion of luteinizing hormone ( $\mathrm{LH})$, which in turn, induces testicular growth and release of testosterone. In contrast, long or increasing days depress LH secretion, testicular growth and then release of testosterone (Muduuli et al., 1979; Rouger, 1974; Pelletier et al., 1988). In rams, short photoperiodic cycles abolish seasonal changes in the activity of the hypothalamo-pituitary axis (Pelletier \& Almeida, 1987). In male goats, rapid changes in photoperiod also abolish seasonal changes in testicular weight (Delgadillo et al., 1991); in this study the blood of the animals was sampled on different occasions to determine the endocrine basis for the abolition of seasonality caused by rapid alternation between long and short days. The present study, using the same animals, determined whether these changes were due to (i) an inadequate response of the pineal gland, (ii) a post-pineal process involving alternation of high and low hypothalamo-pituitary activity or (iii) the absence of changes in hypothalamo-pituitary-testis activity.

\section{Materials and Methods}

Animals. The study was conducted between 1 January 1987 and 31 December 1988 on Alpine and Saanen male goats at the Artificial Insemination Research Station at Rouillé, France $\left(46^{\circ} \mathrm{N}\right)$. The males were $346 \pm 7$ days old (mean \pm s.e.m.) at the beginning of the experiment. On 20 December 1986, they were allocated to 3 groups of 6 animals according to breed, body and testicular weight and sperm production during their first sexual season (September to December 1986). Animals were fed daily with $1.0 \mathrm{~kg}$ of hay, $0.6 \mathrm{~kg}$ of barley straw, $0.6 \mathrm{~kg}$ of oats and $0.4 \mathrm{~kg}$ of commercial concentrate with free access to water.

Photoperiodic treatments. Group I remained in open sheds in individual pens $(2.5 \times 1.1 \mathrm{~m})$ under natural daylength and ambient temperature; photoperiod varied from $16 \mathrm{~h}$ of light, at the summer solstice, to $8 \mathrm{~h}$ of light, at the winter soistice (Fig. la). All goats from groups 2 and 3 were placed in individual pens $(1.8 \times 1.7 \mathrm{~m})$ in a light proof building $(5.8 \times 3.6 \mathrm{~m})$. Group 2 animals were exposed alternately to 1 month of long days $(16 \mathrm{~h}$ light: $8 \mathrm{~h}$ dark) and $1 \mathrm{month}$ of short days ( $8 \mathrm{~h}$ light: $16 \mathrm{~h}$ dark; Fig. $1 \mathrm{~b}$ ). Group 3 animals were exposed alternately to 2 months of long days and 2 months of short days (Fig. Ic). Photoperiod was regulated by an electric clock that operated bulbs at $300 \mathrm{~lx}$ laterally to the bucks' eyes. Lights were turned on at $07: 00 \mathrm{~h}$ and turned off at 23:00 h in long days and 15:00 h in short days.

Blood sampling and assays. All blood samples were collected by jugular venepuncture and plasma was obtained after centrifugation at $2500 \mathrm{~g}$ for $20 \mathrm{~min}$, and stored at $-15^{\circ} \mathrm{C}$ (see Fig. 1 for times of sampling).

To measure melatonin in bucks in group 1, blood samples were taken once an hour for $25 \mathrm{~h}$ in December, February and June. In groups 2 and 3, samples were taken at the end of a period of long days and the end of a period of short days. In all groups, blood was sampled 11 months after the start of the experiment. A dim red light producing $<3 \mathrm{~lx}$, was used to facilitate collection of blood at night. Melatonin was assayed by radioimmunoassay in duplicate, in $100-\mu \mathrm{l}$ samples of plasma as described by Fraser et al. (1983), using an antibody first raised by Tillet et al. (1986). Sensitivity, defined as +2 s.d. of the buffer control, was $5 \mathrm{pg} / \mathrm{ml}$. Intra-assay coefficient of variation (CV), calculated from 6 reference plasma samples from pools of known value placed between every 100 unknown samples, was $11 \cdot 1 \%$. Interassay $\mathrm{CV}$ of the two assays, calculated using the mean value of the reference samples was $26.6 \%$.

To determine prolactin concentration in the 3 groups, a blood sample was obtained every 7 days at $14: 00 \mathrm{~h}$ throughout the study. Prolactin was measured by radioimmunoassay in duplicate, in 50- $\mu$ l plasma samples according to the technique described by Kann (1971). Sensitivity was $2 \mathrm{ng} / \mathrm{ml}$. Intra-assay CV, calculated as for the melatonin assay, was $29 \cdot 2 \%$.

To determine $\mathrm{LH}$ and testosterone concentrations in group 1, blood samples were collected every $20 \mathrm{~min}$ for $8 \mathrm{~h}$ once a month from September 1987 to August 1988. The profiles of these hormones in groups 2 and 3, were determined 4 times throughout the study from 9 months after the start of the experiment; blood samples were taken at the middle and end of each of a long-day and short-day period. Blood samples were also obtained once every 7 days at 14:00 h throughout the year from the three groups for testosterone assay (same samples as used for prolactin concentration).

LH was measured by radioimmunoassay in duplicate, in 100- $\mu$ l samples in an ovine assay developed by Pelletier et al. (1982) and validated for goats by Chemineau et al. (1982) and modified by Montgomery et al. (1985). Sensitivity was $0.08 \mathrm{ng} / \mathrm{ml}$. Intra-assay and interassay $\mathrm{CV}$, calculated as for the melatonin assay, was 13.0 and $10.7 \%$, respectively.

Testosterone was measured by radioimmunoassay in 50- $\mu 1$ samples using the method described by Garnier $e t$ al. (1978). Sensitivity was $0.01 \mathrm{ng} / \mathrm{ml}$. Intra-assay and interassay CV, calculated as for the melatonin assay, was 16.6 and $8 \cdot 1 \%$, respectively.

Statistical analysis. To compare the nocturnal and diurnal concentrations of melatonin in the 3 groups during long and short days and to assess the effect of month, the individual values for each blood sample were analysed by ANOVA with repeated measures (male, time) (Dagnélie, 1969). The nocturnal melatonin concentrations of the 3 groups were 


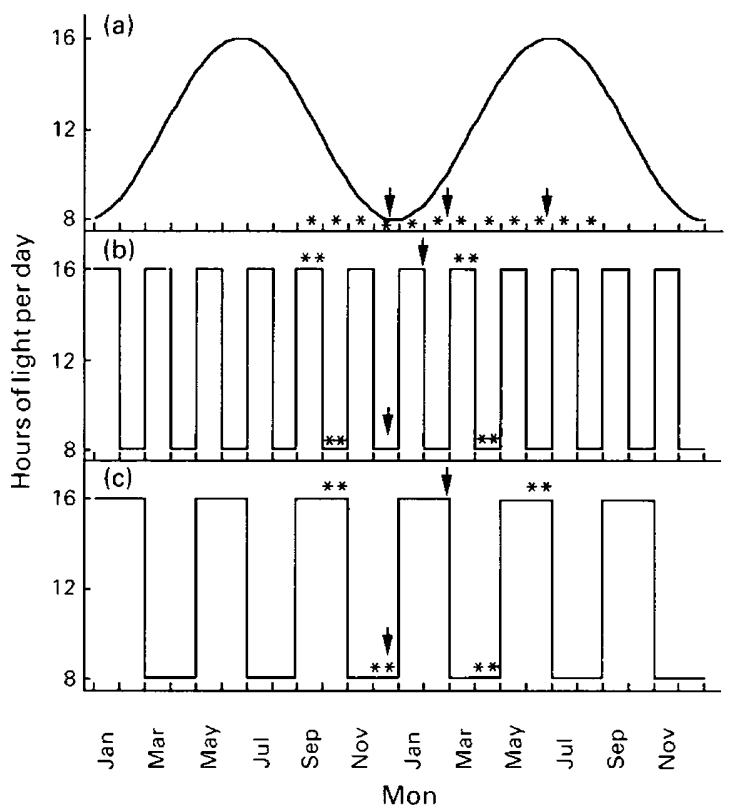

Fig. 1. Photoperiodic treatments applied to 3 groups of Alpine and Saanen male goats for 2 consecutive years. (a) Group 1: natural photoperiodic variations at $46^{\circ} \mathrm{N}$ latitude; (b) group 2: one month of long days alternated with one month of short days; (c) group 3: two months of long days alternated with two months of short days; Long day $=16 \mathrm{~h}$ light: $8 \mathrm{~h}$ dark; short day $=8 \mathrm{~h}$ light: $16 \mathrm{~h}$ dark.

*Indicates the times of blood sampling for LH and testosterone measurements and $\downarrow$ indicates the times of blood sampling for melatonin measurement.

compared by Student's $t$ test (Snedecor \& Cochran, 1980). The duration of high melatonin secretion was analysed only in samples with values $>10 \mathrm{pg} / \mathrm{ml}$.

To analyse weekly the samples for prolactin and testosterone concentrations, we used the following methods: in group 1 monthly means ( 4 or 5 points/male) were calculated and analysed by ANOvA with repeated measures (males, time); in groups 2 and 3, mean concentrations during 2 consecutive (group 2) or successive (group 3) months of long days were calculated. The same procedures were used to calculate the mean concentrations during short days. The mean concentrations were then analysed by ANOVA with repeated measures (group, prevailing daylength and time). For groups 2 and 3, individual means of the highest and lowest values during long and short days were calculated.

The profiles were analysed for LH pulses using the 'pulsar' algorithm, developed by Merriam \& Wachter (1982). The $G$ parameters (the number of standard deviations by which a peak must exceed the baseline in order to be classed as a pulse) were $3 \cdot 00,2 \cdot 00,1 \cdot 55,1 \cdot 13$, and 0.83 for Gl $-\mathrm{G} 5$, respectively, these being the requirements by which $\mathrm{LH}$ pulses, composed of 1-5 samples, must exceed the baseline. The Baxter parameters, which describe the parabolic relationship between the concentration of the hormone in a sample and the standard deviation (assay variation) about that concentration, were $0.01344\left(\mathrm{~b}_{1}, y\right.$ intercept $), 0.03813\left(\mathrm{~b}_{2}, x\right.$ coefficient $)$ and $0.00323\left(\mathrm{~b}_{3}, x^{2}\right.$ coefficient $)$.

Individual mean concentration, mean pulse frequency, baseline and mean pulse amplitude (the difference between the peak of the pulse and the preceding nadir) of LH were calculated for each profile and analysed by ANOVA.

\section{Results}

\section{Melatonin}

In group 1 there were significant effects of night vs. day $(P<0.0001)$, month $(P<0.05)$ and interaction between these two parameters $(P<0.05)$ on plasma melatonin concentrations (Fig. 2$)$. Melatonin concentrations in group 1 , were always higher during the night than during the day. The duration of high melatonin secretion (values $>10 \mathrm{pg} / \mathrm{ml}$ ) also varied significantly with daylength: December, $15 \cdot 3 \pm 0 \cdot 6 \mathrm{~h}$; February, 13.3 $\pm 0 \cdot 6 ;$ June, $8 \cdot 7 \pm 0 \cdot 8(P<0 \cdot 0001)$. 

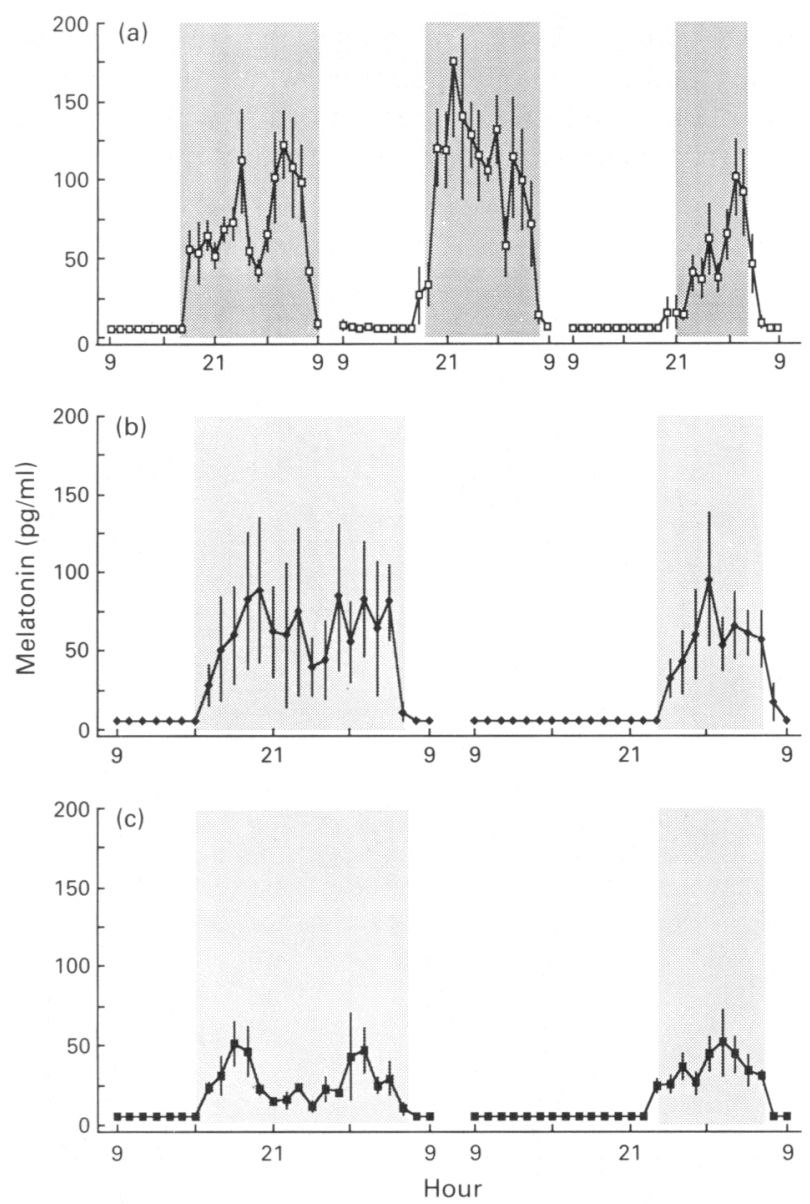

Fig. 2. Mean \pm s.e.m. hourly concentration of plasma melatonin in male goats of (a) group 1, sampling periods in December, February and June; (b) group 2 and (c) group 3, sampling periods in short days and long days. The grey areas indicate the dark period.

In groups 2 and 3 , there was a significant difference between nocturnal and diurnal concentrations of melatonin $(P<0.0001)$. In long and short days, the mean plasma melatonin concentration was higher during the night than during the day (Fig. 2). In these groups, the duration of high melatonin secretion was influenced by daylength $(P<0.0001): 14 \cdot 7 \pm 0.4 \mathrm{~h}$ during short days and $8.0 \pm 0.3 \mathrm{~h}$ during long days in group 2 and $12.8 \pm 1.6 \mathrm{~h}$ and $7.8 \pm 0.6 \mathrm{~h}$ respectively in group 3. There was no significant difference in duration of melatonin secretion between the 3 groups in long or in short days and no significant effect of group on the nocturnal mean melatonin concentrations during long or short days, but melatonin concentration was influenced by time $(P<0.001)$. An interaction between group and time was detected during short, but not during long days. In 10 of 15 occasions, the mean nocturnal melatonin concentrations in group 3 were significantly lower than those of group $1(P<0.05)$. No difference was observed between groups 1 and 2 or between groups 2 and 3. The wide variation in night time concentrations during short days in group 2 was due to high concentrations in one male (see Fig. 2b).

\section{Prolactin}

There was a significant effect of time $(P<0.001)$ on the pattern of prolactin secretion in group I (Fig. 3). Plasma prolactin concentration was highest during spring and summer and lowest during 
autumn and winter: in $1987,4.6 \pm 1.2 \mathrm{ng} / \mathrm{ml}$ in January and $79.6 \pm 15.2 \mathrm{ng} / \mathrm{ml}$ in June; in 1988 , $8 \cdot 7 \pm 3.0 \mathrm{ng} / \mathrm{ml}$ in January and $148 \cdot 3 \pm 60 \cdot 1 \mathrm{ng} / \mathrm{ml}$ in May. There were significant correlations between daylength and plasma prolactin concentrations $(r=0.71 ; P<0.0001)$ and between temperature and plasma prolactin concentrations $(r=0.66 ; P<0.001)$.

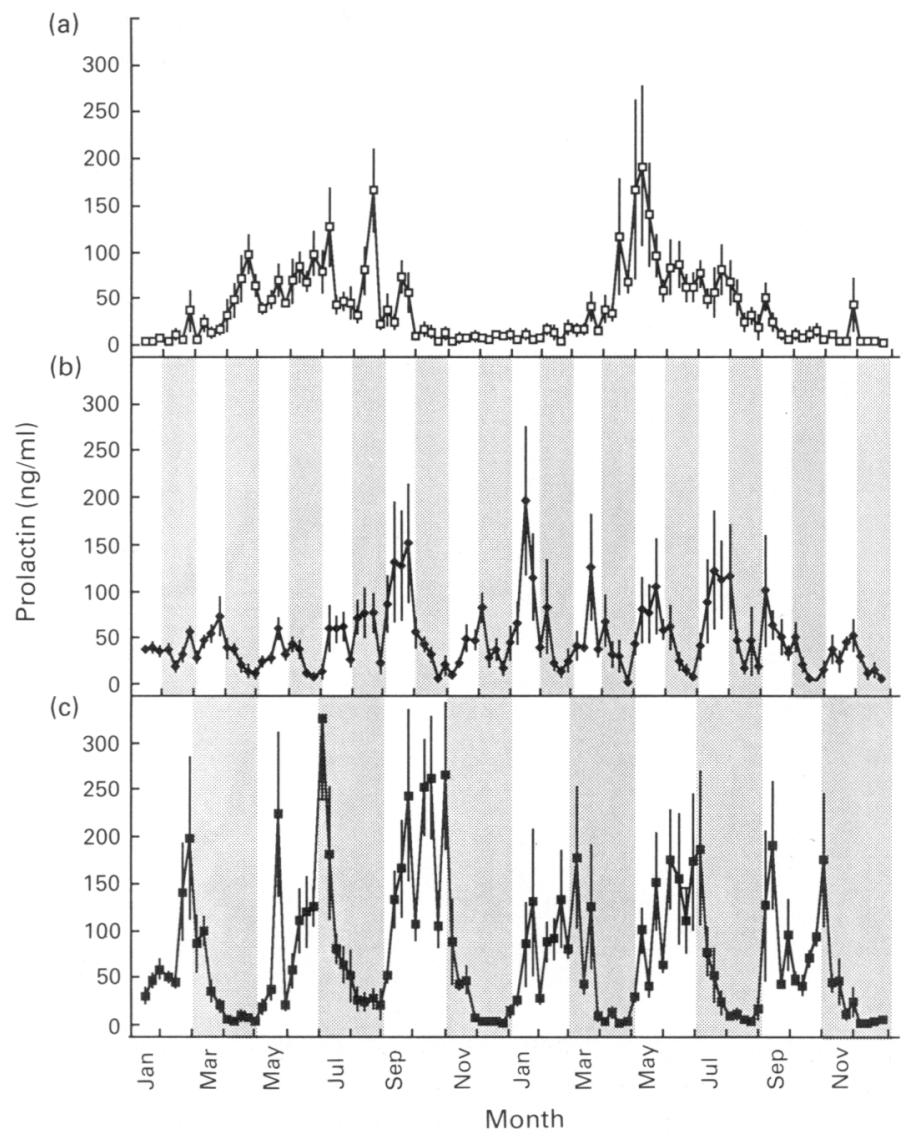

Fig. 3. Mean ( \pm s.e.m.) weekly concentration of plasma prolactin in male goats of (a) group 1; (b) group 2 and (c) group 3. The grey areas indicate the months when the experimental animals were exposed to short days.

Significant effects of time and daylength on prolactin secretion were detected in groups 2 and 3 $(P<0.01$; Fig. 3): concentrations being greatest during long days (group 2: $64.4 \pm 6.8 \mathrm{mg} / \mathrm{ml}$; group 3: $102.3 \pm 15.7 \mathrm{ng} / \mathrm{ml})$ and lowest during short days $(35.0 \pm 3.6$ and $46.1 \pm 9.5 \mathrm{ng} / \mathrm{ml}$, respectively). In groups 2 and 3, prolactin secretion increased 1-2 weeks after the shift to long days and decreased 1-2 weeks after the shift to short days.

\section{LH and testosterone}

Mean LH concentrations for group 1 varied significantly with time $(P<0.0001)$; with a decrease from September to January, followed by an increase from March until August (Fig. 4a). The baseline LH (Fig. 4b), LH pulse frequency (Fig. 4c) and LH pulse amplitude (Fig. 4d) also varied significantly with time $(P<0.0001)$ with the maximum pulse frequency in September. Afterwards, this frequency showed no regular trend throughout the study. From September to May, the LH pulse amplitude remained below $0.4 \mathrm{ng} / \mathrm{ml}$, then increased from June. In experimental goats, 
the group daylength interaction $(P<0.05)$ indicated that, in group 2, mean LH concentrations were similar in long and short days (see Fig. 5), while, in group 3, these concentrations were lower in long than in short days (see Fig. 6). There was no significant effect of group, time of cycle or daylength on mean LH concentration. LH pulse frequency varied with time for groups 2 and 3 $(P<0.01)$. A significant effect of daylength $(P<0.05)$ and a group-daylength interaction $(P<0 \cdot 001)$ was demonstrated on LH pulse frequency; there was no significant effect of group and time of cycle. In group 2, the maximum LH pulse frequency occurred during long days $(1 \cdot 1 \pm 0 \cdot 3$ pulses in 8 hours) and the minimum during short days $(0.7 \pm 0.3)$. In group 3 , the maximum pulse frequency occurred during short days $(1.9 \pm 0.3)$ and the minimum during long days $(0.5 \pm 0.2)$. The LH pulse amplitude also varied with time $(P<0.01)$ and daylength $(P<0.05)$ being lower in long days than in short days for groups 2 and 3.
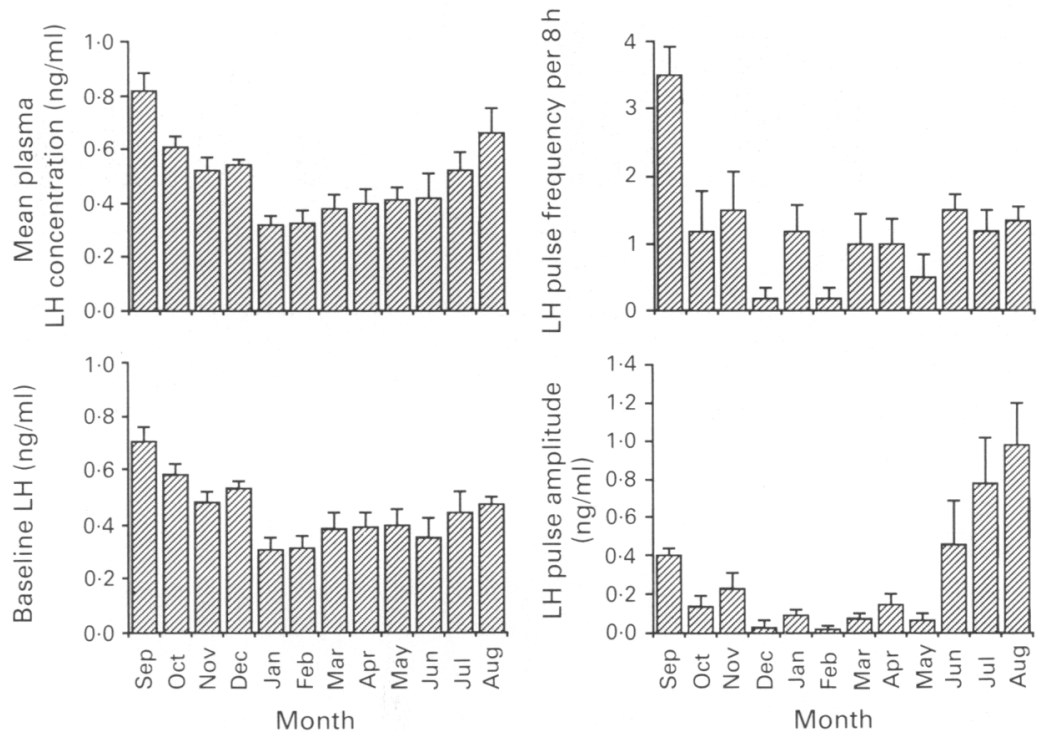

Fig. 4. Monthly changes (mean \pm s.e.m.) in the characteristics of secretion of luteinizing hormone in male goats subjected to natural photoperiodic variations at $46^{\circ} \mathrm{N}$ latitude (group 1).

In group 1, the profiles of testosterone determined from serial blood samples, followed the same pattern as mean LH concentrations (see Fig. 7). Mean plasma testosterone concentrations varied with time $(P<0.0001)$, with maximum concentrations in September and minimum values in May. In groups 2 and 3 , a significant effect of time $(P<0.001)$ and daylength $(P<0.05)$ on testosterone secretion was apparent, with the testosterone profiles following the same pattern as that of $\mathrm{LH}$ pulse frequency (Fig. 7). In fact, the group-daylength interaction $(P<0.0001)$ demonstrated that, in group 2, the mean plasma testosterone concentration was higher during long days than during short days; while in group 3, these concentrations were higher in short days than in long days (Fig. 7). Maximum mean testosterone concentrations of group $2(6 \cdot 1 \pm 0.9 \mathrm{ng} / \mathrm{ml})$ and group 3 $(7.4 \pm 1.5 \mathrm{ng} / \mathrm{ml})$ were lower than those observed in group $1(13.2 \pm 1.5 \mathrm{ng} / \mathrm{ml})$.

Weekly blood samples confirmed the results obtained from serial blood samples. During the two experimental years, dramatic seasonal variations were observed for group 1 (Fig. 8): mean plasma testosterone concentrations varied with time $(P<0.01)$, with maximum concentrations in September, decreasing to minimum values in February. For groups 2 and 3, testosterone secretion was entrained by photoperiodic changes (Fig. 8). Testosterone release varied with both time $(P<0.0001)$ and daylength $(P<0.01)$. Short days stimulated testosterone secretion but mean testosterone concentrations were higher in long days than in short days. In group 3, a clear cycle of 

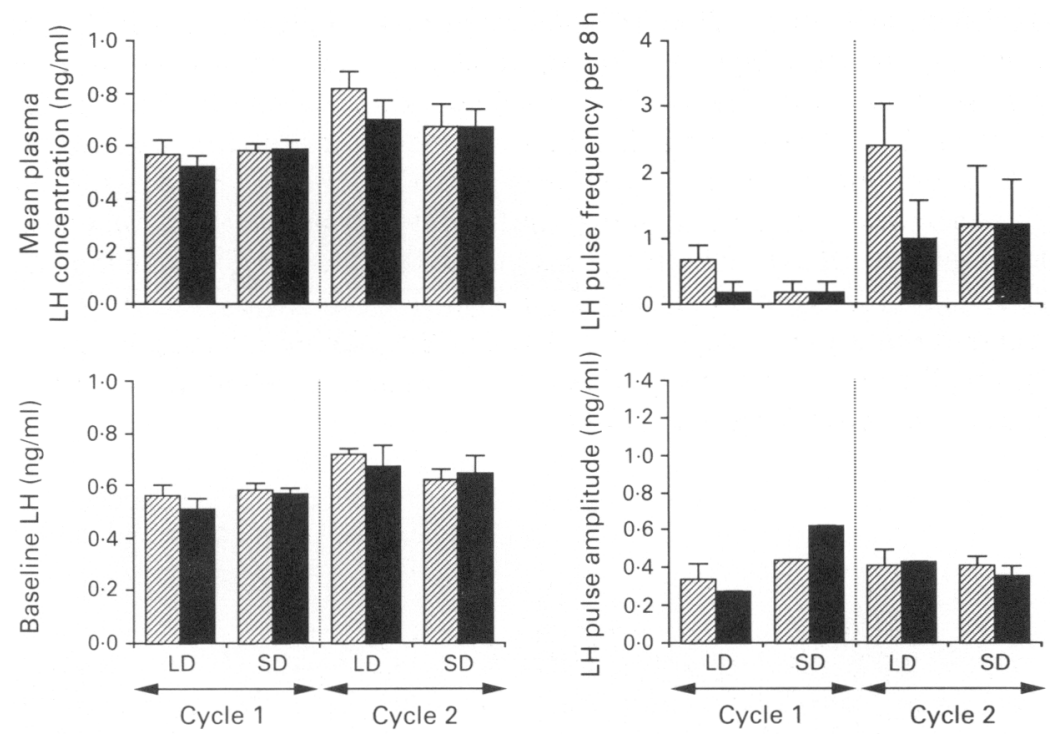

Fig. 5. Pattern of luteinizing hormone (LH) secretion in male goats subjected to one month of long days alternated with one month of short days (group 2). Long day $=16 \mathrm{~h}$ light: $8 \mathrm{~h}$ dark; short day $=8 \mathrm{~h}$ light: $16 \mathrm{~h}$ dark. Cycles 1 and 2 indicate the mean ( \pm s.e.m.) of serial blood samples collected for $8 \mathrm{~h}$ during the middle (shaded) and the end (black) of long and short day periods.
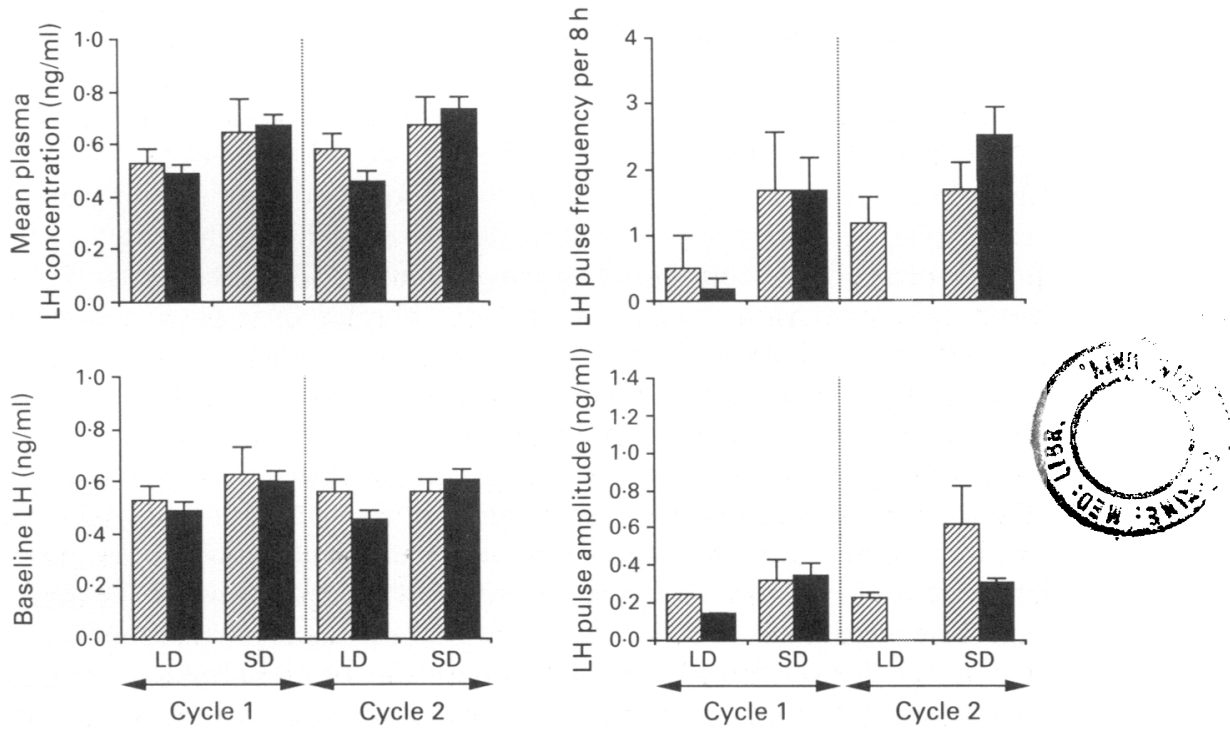

Fig. 6. Pattern of luteinizing hormone $(\mathrm{LH})$ secretion in male goats subjected to two months of long days alternated with two months of short days (group 3). Long day $=16 \mathrm{~h}$ light:8 h dark; short day $=8 \mathrm{~h}$ light: $16 \mathrm{~h}$ dark. Cycles 1 and 2 indicate the mean $( \pm$ s.e.m.) of serial blood samples collected for $8 \mathrm{~h}$ during the middle (shaded) and the end (black) of long and short day periods. 
(a)

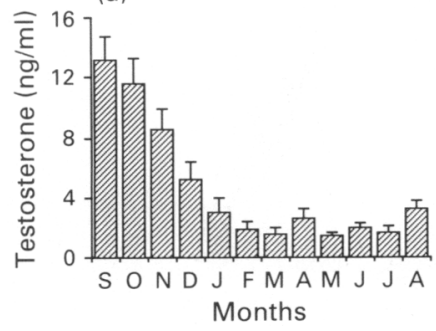

(b)

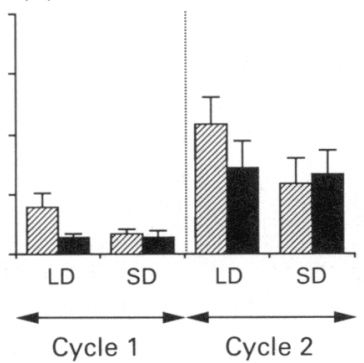

(c)

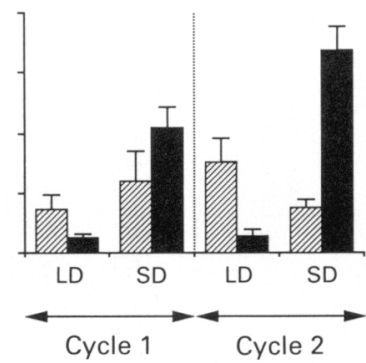

Fig. 7. Changes in the mean ( \pm s.e.m.) concentration of plasma testosterone in male goats of (a) group 1, (b) group 2 and (c) group 3. Cycles 1 and 2 indicate the mean ( \pm s.e.m.) concentration of testosterone in serial blood samples collected for $8 \mathrm{~h}$ during the middle (shaded) and the end (black) of long day (LD) and short day (SD) periods. Long day $=16 \mathrm{~h}$ light: $8 \mathrm{~h}$ dark; short day $=8 \mathrm{~h}$ light: $16 \mathrm{~h}$ dark.

testosterone release, linked to photoperiodic changes, was observed. Testosterone concentrations increased progressively from the fourth week after the switch from long to short days. In group 2 , this cycle was less apparent. Maximum testosterone concentrations in weekly blood samples in both group $2(10.6 \pm 1.8) \mathrm{ng} / \mathrm{ml}$ and group $3(12.0 \pm 1 \cdot 8)$ were significantly lower than those observed in group $1(19 \cdot 4 \pm 1 \cdot 5)$.

\section{Discussion}

The present results showed that, in male goats, short light cycles modified the seasonal variations of $\mathrm{LH}$, testosterone and prolactin secretion usually observed in male goats subjected to natural daylength. The natural variations in hormonal secretion were replaced, in the experimental animals, by short term variations driven by the rapid photoperiodic shifts. The seasonal variations of $\mathrm{LH}$ and testosterone secretion observed in the control bucks were in agreement with those reported by others (Rouger, 1974; Muduuli et al., 1979; Chemineau et al., 1987; Miyamoto et al., 1987).

In experimental groups, melatonin secretion always followed the prevailing photoperiod. The duration of secretion during long days and short days was similar to the length of the dark phase and comparable to that of the control bucks during summer and winter. These observations indicate that males from the experimental groups rapidly adapted their pattern of pineal melatonin secretion to the photoperiod in which they were placed, as previously demonstrated in the ewe by Robinson and Karsch (1987). The pattern of prolactin secretion in the experimental animals also followed the rapid photoperiodic changes. When placed in long days, males increased their plasma prolactin concentrations after $\sim 2$ weeks and these concentrations reached values close to those observed in control bucks during spring and summer. After being transferred to short days, prolactin concentrations decreased after $\sim 2$ weeks, i.e. experimental bucks were able to follow and to interpret the rapid changes in daylength as previously demonstrated in sheep by Pelletier \& Ravault (1988). The abolition or attenuation of seasonal variations observed in these groups, was, consequently, due to a post-pineal processing of the photoperiodic message.

In groups 2 and 3, short days appeared to stimulate LH release. In group 3, mean LH pulse frequency was much higher in short than in long days. In group 2, owing to the very rapid photoperiodic changes, the stimulatory effects of short days were observed during long days: in this group, LH pulsatility was higher in long than in short days. These results are not consistent with those reported by Almeida \& Pelletier (1988), who found that in rams subjected to an alternation between one month of long days and one month of short days, the LH pulse frequency did not vary 


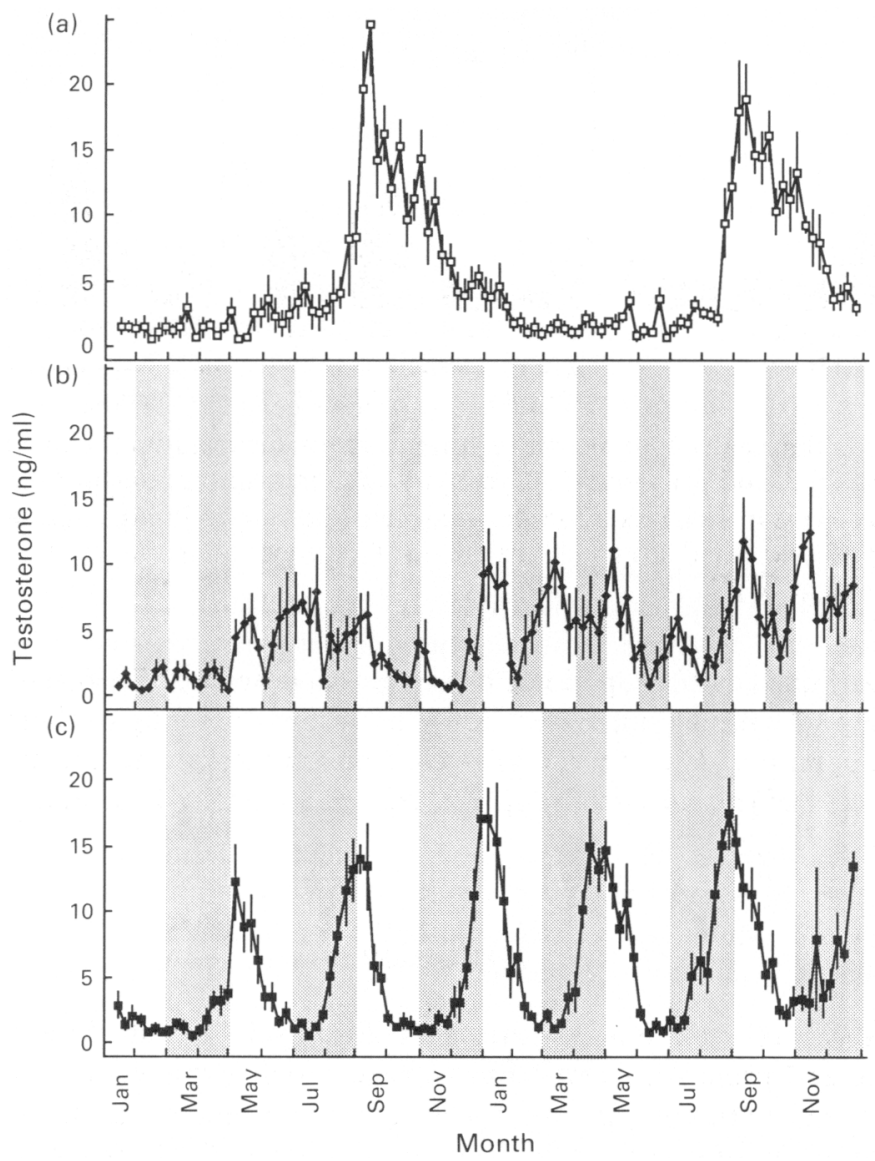

Fig. 8. Weekly changes in the mean $( \pm$ s.e.m.) concentration of plasma testosterone in male goats of (a) group 1, (b) group 2 and (c) group 3. The grey areas indicate the months when the experimental animals were exposed to short days.

significantly with daylength. In group 3, the increased LH pulse frequency during short days enhanced testosterone secretion in the present study and enhanced testicular weight gain as measured in the same animals by Delgadillo et al. (1991). In group 2 goats, this was less apparent owing to very rapid photoperiodic changes and consequently, the increase in LH pulsatility, testosterone secretion in this study and the increase in testicular growth measured in the same animals by Delgadillo et al. (1991) was observed during long days.

It is important to note that the maximum $\mathbf{~} H$ and testosterone values in groups 2 and 3 , were much lower than those observed in control males (group 1). Our results showed that, in group 2, the LH release was sufficient to stimulate testicular activity, but the moderate LH concentrations observed in this group prevented the over-stimulation of testosterone secretion. This probably reduced the inhibition of LH secretion by a negative feedback (Pelletier \& Almeida, 1987; Almeida \& Pelletier, 1988) and allows the maintenance of a high testicular weight, indicating that moderate and frequent stimulation of the testes by $\mathrm{LH}$, and hence corresponding moderate rates of testosterone secretion, may be all that is required to maintain spermatogenesis. For example, testosterone concentration in the testis of the male rat can be reduced by $80 \%$ without compromising spermatogenesis quantitatively (Rommerts, 1988). Interestingly, in group 3, LH and testosterone secretion were higher than in group 2 . It is possible that, in group 3 bucks, these high testosterone concentrations had a negative feedback on LH secretion (Mortimer, 1979; Adams et al., 1988; Sanford \& Ponzilluis, 1989). This could explain, at least in part, the small variations in testicular weight 
observed in group 3 bucks by Delgadillo et al. (1991). However, the abolition (group 2) or attenuation (group 3) of spermatogenetic activity was also clearly due to alternation between high and low hypothalamo-pituitary activity in response to the photoperiodic changes. The synchronous variation in testosterone secretion, indicates that the testis was able to follow these rapid changes in gonadotrophin activity. In both experimental groups it appears that males, even if they interpreted adequately the daylength as indicated by prolactin secretion, did not respond in terms of testosterone secretion to the alternations between long and short days until four months after the start of the experiment, indicating that a period of time is needed for testis activity to respond to the photoperiodic treatments.

FSH (follicle-stimulating hormone) which was not measured for technical reasons, is known to play a central role in the control of spermatogenetic activity in the ram (Lincoln \& Short, 1980). However, it is probable from our results, that FSH is also entrained by light changes as previously demonstrated in Soay rams submitted to alternate periods of 3 months long days and 3 months short days (Lincoln, 1988), and because marked changes of testis weight have previously been correlated with changes in photoperiod (Delgadillo et al., 1991).

It was concluded that, although rapid alternations between long and short days resulted in periods of gonadotrophin stimulation of the testis alternating rapidly with periods of quiescence, high testicular weight was maintained.

We wish to thank $\mathbf{J}$. Pelletier and $\mathbf{J}$. Thimonier for their help in the experimental design of this study; A. Daveau, F. Maurice, B. Leboeuf, J. L. Bonné, D. Bernelas and Y. Berson for their technical assistance; A. Boisseau and J. Boutin for care of the animals; L. Delaby for his help in statistical analysis and B. Malpaux for discussion of the results and assistance with preparation of this manuscript. This experiment was supported by region 'Poitou-Charentes'.

\section{References}

Adams, L.A., Clifton, D.K., Bremer, W.J. \& Steiner, R.A. (1988) Testosterone modulates the differential release of luteinizing hormone and follicle stimulating hormone that occurs in response to changing gonadotrophin-releasing hormone pulse frequency in the male monkey, Macaca fascicularis. Biol. Reprod. $38,156-162$.

Almeida, G. \& Pelletier, J. (1988) Abolition of seasonal testis changes in the Ile-de-France ram by short light cycles: relationship to luteinizing hormone and testosterone release. Theriogenology 29, $681-691$.

Chemineau, P., Gauthier, D., Poirier, J.C. \& Saumande, J. (1982) Plasma levels of LH, FSH, prolactin, oestradiol-17\% and progesterone during natural and induced oestrus in dairy goat. Theriogenology 17, $313-323$.

Chemineau, P., Normant, E., Ravault, J.P. \& Thimonier, J. (1986) Induction and persistence of pituitary and ovarian activity in the out-of-season lactating dairy goat after a treatment combining a skeleton photoperiod, melatonin and the male effect. $J$. Reprod. Fert. 78, 497-504.

Chemineau, P., Daveau, A., Maurice, F. \& Delgadillo, J. (in press) Seasonality of oestrus and ovulation is not modified by subjecting Female Alpine goats to a tropical photoperiod. Small Rumin. Res.

Dagnélie, P. (1969) Théorie et Méthodes Statistiques, vols 1 \& 2. Presses Agronomiques de Gembloux, Gembloux, Belgium.
Delgadillo, J.A., Leboeuf, B. \& Chemineau, P. (I991) Decrease in the seasonality of sexual behavior and sperm production in bucks by exposure to short photoperiodic cycles. Theriogenology 36, 755-770.

Fraser, S., Cowen, P., Franklin, M., Franey, C. \& Arendt, J. (1983) Direct radioimmunoassay for melatonin in plasma. Clin. Chem. 20, 396-397.

Garnier, D.H., Cotta, Y. \& Terqui, M. (1978) Androgen radioimmunoassay in the ram: results of direct plasma testosterone and dehydroepiandrosterone measurement and physiological evaluation. Ann. Biol. anim. Biochem. Biophys. 18, 265-281.

Kann, G. (1971) Dosage radioimmunologique de la prolactine plasmatique chez les ovins. C. r. heb. Séanc. Acad. Sci., Paris, D 272, 2808-2811.

Lincoln, G.A. (1988) Endogenous opioids and the control of $\mathrm{LH}$ secretion during the reproductive cycle in the ram induced by treatment with melatonin. Reprod. Nutr. Dévelop. 28, 527-539.

Lincoln, G.A. \& Short, R.V. (1980) Seasonal breeding: nature's contraceptive. Recent Prog. Horm. Res. 36, $1-52$.

Merriam, G.R., Wachter, K.W. (1982) Algorithms for the study of episodic hormone secretion. Am. J. Physiol. 243, E310-318.

Miyamoto, A., Umezu, M., Hamano, K. \& Masaki, J. (1987) Seasonal changes in inhibin activity in seminal plasma and serum concentrations of FSH, LH and testosterone in male goat (Capra hircus). Theriogenology 28, 67-76. 
Montgomery, G.W., Martin, G.B. \& Pelletier J. (1985) Changes in pulsatile LH secretion after ovariectomy in Ile-de-France ewes in two seasons. $J$. Reprod. Fert. 73, 173-183.

Mortimer, B.L. (1979) The role of the testosterone and other hormones in regulation of LH. J. Steroid. Biochem. 11, 659-661.

Muduuli, S., Sanford, L.M., Palmer, W.M. \& Howland, B.E. (1979) Secretory patterns and circadian and seasonal changes in luteinizing hormone, follicle stimulating hormone, prolactin and testosterone in the male Pygmy goat. J. Anim. Sci. 49, 543- 553.

Pelletier, J. \& Almeida, G. (1987) Short light cycles induce persistent reproductive activity in lle-deFrance rams. J. Reprod. Fert. Suppl. 34, 21 5-226.

Pelletier, J. \& Ravault, J.P. (1988) Day length measurement in rams made permanent breeders by short light cycles. Neuroendocrinol. Lett. 10, 329-336.

Pelletier, J., Garnier, D.H., De Reviers, M.M., Terqui, M. \& Ortavant, R. (1982) Seasonal variation in LH and testosterone release in rams of two breeds. $J$. Reprod. Fert. 64, 341346.

Pelletier, J., Chemineau, P. \& Delgadillo, J.A. (1988) Seasonality of sexual activity and its photoperiodic control in the adult ram and he-goat. In Proc. 11th Int. Congr. Anim. Reprod. \& A. I., Dublin 5, 211-219.
Robinson, J.E. \& Karsch, F.J. (1987) Photoperiodic history and a changing melatonin pattern can determine the neuroendocrine response of the ewe to day length. J. Reprod. Fert. 80, 159-165.

Rommerts, F.F.G. (1988) How much androgen is required for maintenance of spermatogenesis? $J$. Endocr. 116, 7-9.

Rouger, Y. (1974) Etude des interactions de l'environnement et des hormones sexuelles dans la régulation du comportement sexuel des Bovidae. Thèse Doctorat es Sciences Naturelles, Université de Rennes, $197 \mathrm{pp}$.

Sanford, L.M. \& Ponzilius, K.H. (1989) The pattern of $\mathrm{L} H$ release in the aduit ram influences the testicular steroidogenic response to individual $\mathrm{LH}$ pulses and is regulated by testosterone negative feedback. $J$. Androl. 10, 1-10.

Snedecor, G.W. \& Cochran. W.C. (1980) Statistical Methods, 7 th edn., Iowa State University Press, Ames.

Tillet, Y., Ravault, J.P., Selve, C., Eeving, G., Castro, B. \& Dubois, M.P. (1986) Conditions d'utilisation d'anticorps spécifiques pour la visualisation immunohistochimique de la sérotonine et de la mélatonine dans la glande pinéale du mouton. C. $r$. heb. Séanc. Acad. Sci., Paris, III, 303, 77-82.

Received 30 August 1990 